\title{
EFEKTIVITAS PENERAPAN SANKSI ADAT DALAM PENYELESAIAN SENGKETA MELALUI PERADILAN ADAT GAYO DI ACEH TENGAH
}

\author{
Rahmina $^{1}$ \\ Teuku Muttaqin Mansur ${ }^{2}$ \\ M. Adli Abdullah ${ }^{3}$
${ }^{1}$ Magister Ilmu Hukum, Fakultas Hukum Universitas Syiah Kuala Banda Aceh, Indonesia
${ }^{2}$ Coresponding author: Teuku Muttaqin Mansur; email:tmuttaqien@unsyiah.ac.id
${ }^{23}$ Fakultas Hukum Universitas Syiah Kuala Banda Aceh, Indonesia \\ E-mail: rahmina95@yahoo.co.id
}

Diterima: 09/11/2019; Disetujui: 29/11/2019

\begin{abstract}
ABSTRAK
Hukum Adat Gayo merupakan perintah yang harus atau boleh dilakukan dan larangan yang tidak boleh dilakukan. Pelanggaran yang dilakukan terhadap hukum adat akan diberikan sanksi, sanksi adat adalah pemberian hukuman kepada para pelanggar hukum adat yang sanksinya ditetapkan oleh tokoh adat, pemberian sanksi ini berbeda-beda sesuai dengan pelanggaran yang dilakukan. Tujuan dari penulisan ini adalah untuk mengidentifikasi jenis-jenis sanksi adat Gayo dan untuk melihat keefektifan sanksi adat dalam menyelesaikan sengketa-sengketa yang muncul dikalangan masyarakat Gayo di kabupaten Aceh Tengah. Penulisan ini menggunakan metode penelitian yuridis empiris, datanya diambil dari bahan hukum primer dan skunder juga wawancara dengan responden dan informan. Data dianalisis menggunakan pendekatan diskriptif kualitatif. Penelitian ini dilakukan di Kabupaten Aceh Tengah. Hasil penelitian ini menunjukan bahwasanya jenis sanksi adat Gayo yang diberikan kepada pelanggar hukum adat Gayo berbeda-beda, sesuai dengan pelanggaran yang dilakukan, ada yang hanya dengan kata maaf ( $m a$ 'as) ada juga yang sampai di usir dari kampung dan tidak boleh lagi kembali ke kampung tersebut (Jeret Naru). Sanksi adat berlaku efektif dalam mengurangi pelanggaran-pelanggaran hukum adat Gayo, dalam arti para pelanggar menerima keputusan dan bersedia melaksanakan sanksi yang diberikan oleh tokoh adat kampung. Diharapkan kepada tokoh adat supaya mensosialisasikan hukum adat Gayo kepada generasi muda supaya tidak terjadi pelanggaran-pelanggaran terhadap hukum adat Gayo.
\end{abstract}

Keywords: Effectiveness, Customary Sanctions, Customary Dispute Resolution 


\begin{abstract}
Gayo customary law is an order that must or may be done and a prohibition that must not be done. Violations committed against customary law will be given sanctions, customary sanctions are punishment for violators of customary law whose sanctions are determined by traditional leaders, giving these sanctions vary according to the violations committed. The purpose of this paper is to identify the types of Gayo adat sanctions and to see the effectiveness of adat sanctions in resolving disputes that arise among the Gayo community in Central Aceh district. This writing uses empirical juridical research methods, the data is taken from primary and secondary legal materials as well as interviews with respondents and informants. Data were analyzed using a qualitative descriptive approach. This research was conducted in Central Aceh District. The results of this study indicate that the types of Gayo adat sanctions imposed on violators of Gayo adat law differ, according to the violations committed, there are only those with the word sorry (ma'as) and some have been expelled from the village and may no longer return to the village (Jeret Naru). Customary sanctions are effective in reducing violations of Gayo customary law, in the sense that violators accept the decision and are willing to implement the sanctions given by the traditional leaders of the village. It is expected that traditional leaders will socialize Gayo customary law to the younger generation so that violations against Gayo customary law do not occur.
\end{abstract}

Keywords: Effectiveness, Customary Sanctions, Customary Dispute Resolution 


\section{PENDAHULUAN}

Dilihat dari kajian-kajian tentang penyelesaian sengketa, maka tergambar bahwa dalam masyarakat hukum adat sudah sejak lama sengketa-sengketa yang terjadi diselesaikan dengan cara musyawarah dan mufakat melalui lembaga-lembaga adat seperti peradilan adat. Corak-corak ruang penyelesaiannya tersebut diistilahkan dengan "sejenis peradilan".

Peradilan adat memiliki kekuatan yang mendasar dalam pribadi masyarakat Indonesia, hal ini terlihat dalam setiap penyelesaian sengketa yang ada dalam masyarakat indonesia, ketika ada persengketaan antar masyarakat, maka penyelesaiannya dilakukan dengan cara musyawarah dan mufakat. Penyelesaian dengan cara musyawarah dan mufakat menjadi sesuatu yang selalu ditekuni dalam setiap penyelesaian sengketa.

Peradilan adat tidak dapat dipisahkan dalam sistem hukum Indonesia. Bekerjanya hukum adat dan institusinya, tidak lepas dari kemajuan pengakuan konstitusi, khususnya Pasal 18 B ayat (1) dan ayat (2) serta Pasal 28 I ayat (3) UndangUndang Dasar Negara Republik Indonesia Tahun 1945 (UUD 1945).

Berdasarkan Pasal 18 B ayat (1) UUD 1945 Negara mengakui dan menghormati satuan-satuan pemerintahan daerah yang bersifat khusus atau bersifat istimewa yang diatur dengan undang-undang. Pasal 18 B ayat (2) UUD 1945 mengakui dan menghormati kesatuan-kesatuan masyarakat hukum adat beserta hak-hak tradisionalnya sepanjang masih hidup dan sesuai dengan perkembangan masyarakat dan prinsip Negara Kesatuan Republik Indonesia, yang diatur dalam undang-undang. Pasal 28 I ayat (3) UUD 1945 Identitas budaya dan hak masyarakat tradisional dihormati selaras dengan perkembangan zaman dan peradaban.

${ }^{1}$ Teuku Djuned dalam Sulaiman, Hukum Peradilan Adat di Indonesia, Pale Media Indonesia, Yogyakarta 2012, hlm. 29.
Bergulirnya reformasi di Indonesia, melahirkan pola pemerintahan yang tidak lagi tersentralisasi. Beberapa UU yang lahir pasca reformasi, semakin membuka peluang bagi otonomi yang lebih besar bagi daerah, antara lain lahirnya Undang-Undang No 44 Tahun 1999 tentang Penyelenggaraan Keistimewaan Provinsi Istimewa Aceh dan Undang-Undang No 18 Tahun 2001 tentang Otonomi Khusus yang diganti dengan Undang-Undang No 11 Tahun 2006 tentang Pemerintah Aceh.

Keberadaan hukum adat di Aceh semakin kuat dengan lahirnya UUPA. Hal ini karena adanya pengakuan kepada lembaga adat. Lembaga adat diberikan kewenangan menegakkan hukum adat, sebagaimana diatur dalam BAB XIII Pasal 98 tentang lembaga adat UUPA. ${ }^{2}$

Berdasarkan Pasal 98 ayat (1) UUPA "Lembaga adat berfungsi dan berperan sebagai wahana partisipasi masyarakat dalam penyelenggaraan Pemerintah Aceh dan Pemerintahan Kabupaten/kota di bidang keamanan, ketentraman, kerukunan dan ketertiban". Pasal 98 ayat (2) UUPA “ Penyeles aian masalah sosial kemasyarakatan secara adat ditempuh melalui lembaga adat.

Ketentuan lebih lanjut mengenai tugas, wewenang, hak dan kewajiban lembaga adat, pemberdayaan adat dan adat istiadat diatur lebih lanjut dengan Qanun Aceh. Dengan demikian, berdasarkan amanah UUPA tersebut dibentuklah turunan peraturan daerah (Qanun Aceh) untuk menguatkan keberadaan lembaga adat (peradilan adat), struktur lembaga adat dan hukum adat. Adapun Qanun-Qanun Aceh yang dimaksud adalah, sebagai berikut;

1. Qanun Aceh Aceh No 9 Tahun 2008 tentang Pembinaan Kehidupan Adat dan Adat Istiadat, 
2. Qanun Aceh Aceh No 10 Tahun 2008 tentang Lembaga Adat,

3. Qanun Aceh Aceh No 3 Tahun 2009 tentang Tata Cara Pemilihan dan Pemberhentian Mukim dan

4. Qanun Aceh Aceh No 4 Tahun 2009 tentang Tata Cara Pemilihan dan Pemberhentian Keuchik.

Semangat untuk menghidupkan kembali lembaga adat sebagai struktur kelembagaan lokal dalam penyelesaian sengketa juga diikuti oleh beberapa daerah Kabupaten/ Kota di Provinsi Aceh. Salah satunyan Qanun Kabupaten Aceh Tengah No 09 Tahun 2002 tentan Hukum Adat Gayo Pasal 8, disebutkan bahwa fungsi Sarak Opat sebagai lembaga adat adalah:

a. Sarak Opat berperan aktif mencegah perbuatan sumang/ sumbang

b. Sarak Opat dapat menindak perbuatan sumang

c. Sarak Opat melaksanakan hukum adat istiadat, kebiasaa-kebiasaan dan sanksi adat.

d. Sarak Opat menyelesaikan Kemalun Edet Empat perkara, Madu Opat.

e. Sarak Opat menyelesaikan yang menyalahi adat empat perbuatan.

Kabupaten Aceh Tengah adalah salah satu daerah yang mayoritas masyarakatnya bersukukan Gayo, dimana peradilan adat dijalankan oleh sarak opat. Sarak opat adalah tokoh adat kampung dan berperan aktif dalam menyelesaikan sengketa antar masyarakat dan menjaga ketertiban kehidupan masyarakat Gayo. Penyelesaian sengketa melalui peradilan Gayo dilaksanakan dengan cara musyawarah yang dilakukan oleh sarak opat dan masyarakat yang bersengketa, hasil putusan peradilan adat Gayo memiliki ketentuan tertentu yaitu berupa pemberian sanksi adat.

Sanksi adat dalam masyarakat Gayo memiliki karakteristik tersendiri dan sudah lama berkembang dan diterapkan dalam kehidupan masyarakat Gayo, setiap permaslahan diselesaiakan secara musyawarah, namun penetapan dan penetuan sanksi apa yang akan diberlakukan dilihat dari bentuk-bentuk pertikaian yang sedang dihadapi.

Masyarakat Gayo memiliki berbagai macam bentuk sanksi ada yang ringan dan ada juga yang berat seperti diusir dari kampung dan lain sebagainya. Penerapan sanksi-sanksi dalam setiap persengketaan merupakan salah satu bentuk menjaga hubungan kekeluaragaan antar masyarakat supaya tetap terjaga.

Berdasarkan uarain di atas maka adapun yang menjadi identifikasi masalahnya apa saja bentuk-bentuk sanksi adat dalam masyarakat Gayo dan efektivitas penerapan sanksi adat dalam penyelesaian sengketa melalui peradilan adat gayo di aceh tengah.

\section{METODE PENELITIAN}

Metode yang digunakan yuridis empiris, dengan melakukan wawancara dengan responden dan informan. Data dianalisis menggunakan pendekatan diskriptif kualitatif.

\section{HASIL PENELITIAN DAN PEMBAHASAN}

Masyarakat Gayo memiliki kaidah-kaidah kehidupan yang harus selalu dijaga, dipraktekan dan dikembangkan dalam kehidupan, dengan tujuan untuk menjaga keseimbangan dalam kegiatan bermasyarakat. Kaidah-kaidah tersebut kemudian dijadikan sebagai pedoman dalam membina kehidupan yang baik dan bermartabat. Kaidah-kaidah ini yang tersusun rapi dalam adat istiadat dan budaya Gayo. Adat istiadat dan budaya Gayo kemudian dijadikan pedoman untuk mengatur kehidupan bermasyarakat yang kemudian disebut dengan edet, (hukum adat).

Hidup rukun bagi masyarakat gampong (istilah Gayonya Kampung) bagaikan hidup satu ayah satu ibu, dan rasa persaudaraan inilah yang selalu tercermin dalam diri warga gampong, sehingga sengketa/perselisihan yang terjadi di tengah-tengah mereka selalu diupayakan 
diselesaikan dengan hukum adat yang berlaku dalam wilayahnya. ${ }^{3}$

Bagi masyarakat adat gampong, kekeluargaan merupakan prinsip utama dalam musyawarah peradilan adat Aceh. Ketika persoalan dan peristiwa hukum terjadi dalam masyarakat, selalu diupayakan penyelesaiannya dengan cara kekeluargaan dan mengutamakan prinsip keiklasan antar sesama mereka. Penyelesaian sengketa/perselisihan dengan hukum adat merupakan perbuatan baik dan mulia kedudukannya baik secara hidup bersama di dunia maupun disisi Allah, karena hukum adat dengan hukum Islam sangat erat hubungannya, asas-asas yang terdapat dalam hukum adat Aceh merupakan ajaran dalam Islam. Dengan demikian jelas bahwa penyelesaian sengketa/perselisihan secara adat tidak bertentangan dengan Agama Islam yang mereka anut, yang menganjurkan perdamaian. $^{4}$

Hasil studi di Aceh menunjukan bahwa kasus-kasus sengketa dalam masyarakat Aceh masih dominan diselesaikan pada peradilan adat. Fenomena ini, sesuai dengan hasil survei kepuasan masyarakat terhadap peradilan adat di Aceh yang dilakukan oleh United Nation Development Program (UNDP). Hasil survei tersebut menunjukkan bahwa, masyarakat menyatakan sangat puas $(90 \%$ hingga $91 \%$ ) merasa puas menyelesaikan sengketa pada peradilan adat. Kepuasan responden diakui karena mereka masih menghormati Hakim Peradilan adat separti Keuchik dan Imeum Mukim sebagai pihak yang menyelesaikan perselisihan. Alasan lain dari responden, ialah persidangan pada peradilan adat bersifat perdamaian sehingga dapat mempererat keharmonisasian dan tali persaudaraan di dalam masyarakat sendiri. ${ }^{5}$

\footnotetext{
Taqwaddin Husin, "Penyelesaian Sengketa/Perselisihan Secara Adat Gampong di Aceh, Kanun Jurnal Ilmu Hukum, 2015, No. 67, Th. XVII,(511532), hlm 517.

${ }^{4}$ Ibid, hlm. 518.

${ }^{5}$ Teuku Muttaqin Mansur, "Kedudukan Mahkamah Adat setelah Undang-Undang tentang Pemerintahan Aceh",
}

Aceh Tengah yang mayoritas bersukukan Gayo, dan hukum adat yang berlaku juga hukum adat Gayo (edet). Edet berperan penting dalam membentuk kehidupan masyarakat yang aman, damai dan tentram, adapun salah satu bentuk untuk tetap menjaga keseimbangan antar masyarakat adalah dengan cara memberikan sanksi kepada pihak-pihak yang membuat keseimbangan masyarakat yang lain tergangu. Adanya ketidak seimbangan dalam masyarakat membuat hubungan masyarakat terpecah belah, sehingga tidak ada lagi rasa kekeluargaan dan rasa saling tolong menolong, maka dalam hal ini edet yang dijalankan oleh sarak opat harus dapat memulihkan kembali hubungan antar masyarakat, salah satunya dengan cara memberikan sanksi kepada salah satu pihak yang merugikan pihak yang lainnya.

Edet Gayo memiliki karakteristik tersendiri dalam menerapakan sanksi adat, dimana berbeda dengan penerapan sanksi adat di daerah yang lain. Edet Gayo memiliki 10 (sepuluh) bentuk-bentuk hukuman dalam penyelesaian sengketa di masyarakat Gayo: ${ }^{6}$

1. Nasihat

Nasihat merupakan bentuk penyelesaian sengketa yang paling ringan, bentuk penyelesaian ini dalam prosesnya hanya memanggil para pihak yang bersengketa, kemudian dinasehati, isi nasihat menjelaskan dampak buruk dari apa yang dilakukan dan para penasehat juga berharap supaya para pihak yang bersengketa tidak lagi mengulangi kesalahan yang sama. Penyelesaian dalam bentuk nasihat tidak ada denda, nasihat berlaku pada kasus ringan.

\section{Salah Bersemah Ilit Berisi}

Salah bersemah (akupe salah) sadar akan kesalahan yang dilakukan/

Kanun Jurnal Ilmu Hukum, 2016, Vol. 18, No. 2, (209-218), hlm. 215-216.

${ }^{6}$ M Jusin Saleh, MBA,Ketua Majlis Adat Gayo, Kabupatean Aceh Tengah, Wawancara, tanggal 2 Juni 2019. 
mengakui kesalahan yang telah dilakukan, ilit berisi maksudnya pemberian yang layak diberikan kepada orang yang disalahi dan layak diterima, ketika pihak yang salah sadar melakukan kesalahan maka pihak yang mengakui kesalahan berhak memberi sesuatu yang layak dan layak diterima. Meminta maaf kepada yang kita salahi dan ada kelayakan untuk memberi. Berdasarkan musyawarah dengan Sarak Opat.

3. Rujuk, ma'as, diet dan bela

Rujuk salah satu pihak yang bersengketa mengakui kesalahanya, dan meminta penyelesaian kepada peradilan adat yaitu "Sarak Opat". Ma'as yaitu ketika para pihak saling mengakui kesalahan, dan saling meminta maaf "keta bersiamaapen kite". Diet yaitu denda yang harus diberikan kepada pihak yang disalahi, "sidah kubir, sidah kosah ganti e" dalam arti berapa denda yang harus diberikan kepada korban dalam sengketa tersebut. Bela yaitu berupa negosiasi dalam hal menetapkan denda yang diberikan, dalam hal ini pihak korban yang menetapkan jumlah dendanya, dan pelaku dapat meminta kurang jika denda yang diminta terlalu tinggi atau sebaliknya.

4. Gere genapi

Seseorang yang melakukan kerusuhan di kampung, ketika dinasehati pelaku tidak mendengarkan dalam arti tidak mematuhi putusan Sarak Opat "Hana si ejeri gre pengene", dan pekerjaanya selalu membuat keonaran di kampung tersebut dalam arti perbuatannya sudah meresahkan masyarakat, kemudian tokoh lembaga adat Sarak Opat dan masayarakat kampung mengambil keputusan bahawa orang tersebut yaitu Gere Genapi, maksudnya pelaku tersebut masih boleh tinggal di kampung tetapi dia dikucilkan dan tidak diikutsertakan dalam kegiatan sosial di kampung dalam hal ini lebih kepada beban mental. Ketika ada acara apa saja di kampung maka dia tidak diikutsertakan.

\section{Parak}

Ketika melakukan pernikahan satu kampung, maka akan diberikan sanksi berupa Parak yaitu diasingkan maksimal 2 tahun meninggalkan kampung dan boleh kembali lagi ke kampung dengan syarat harus menyembelih kerbau, kerbau adalah denda paling tinggi.

6. Jeret naru

Pelaku tidak boleh pulang seumur hidupnya ke kampung, dan pelaku telah dianggap mati hal ini dalam sengketa yang bertentangan dengan agama. Seperti pernikahan satu wali.

\section{Bersih lante}

Keonaran yang dilakukan para pihak baik yang terjadi di kampung sendiri atau kampung orang lain. Maka para pelaku harus Bersihkan Lante, berapa kelayakan yang diberikan, paling terberat kambing, dan dalam hal ini juga ada pengkondisian.

8. Rayoh berpeniri, luke bersalin, kemung berpenempu

Bentuk ini diterapkan dalam sengketa perkelahian, Rayoh berpeniri, maksudnya apabila dalam kejadian tersebut menyebabkan luka berat dan banyak mengeluarkan darah. Luke bersalin, maksudnya korban mengalami luka berat maka lukanya tersebut harus di obati, kemung berpenempu, maksudnya hanya didapati lukanya bengkak saja maka yang diobati bengkaknya saja.

9. Serlut

Serlut adalah sanksi yang diberikan kepada pemerintahan tepatnya di masyarakat Gayo yaitu tokoh lembaga adat Sarak Opat. Dalam hal ini maksudnya jabatan dicabut secara paksa. Adapun istilah Gayonya adalah:

Ike Reje salah, Reje i siut, ike olok tu slah e Reje i siut sampek mupot.

Imem salah, imem i anut, ike olok tu salahe $i$ anut sawah bulut. 
Ike Petue salah, Petue i gelot, ike olok tu slaha e i kerot.

Ike rakyat salah si patut-patute.

Bentuk serlut ini adalah berupa sanksi yang diterapkan kepada aparat kampung yaitu Sarak Opat jika mereka melakukan kesalahan. Apabila kesalahannya masih dalam kategori ringan intinya masih dapat dimaafkan, maka yang dilakukan hanya mencabut jabatannya tetapi masih dapat berkontribusi untuk kampung, namun jika kesalahan pelaku sudah berat maka selain dicabut jabatannya pihak tersebut juga tidak boleh lagi berkontribusi terhadap kampung, baik dalam bidang apa saja.

10. Unuh

Hukum bunuh ini baru dapat
dilaksanakan apa bila agama
mengijinkan untuk dibunuh karena
kesalahnnya, maka hukum unuh akan
diberlakukan. Dalam hukum Unuh ini
maka tidak boleh terjadi pertumpahan
darah sedikit pun. "Sarah rayoh epe enti
tareng $i$ denuie" ada beberapa cara
pelaksanaan Unuh ini yaitu:

a. Cengkek (hukuman bunuh dengan cara mencekik)

b. Dedok (hukuman bunuh dengan cara menenggelamkan kepala kedalam air)

c. Kerusung, baden ne $i$ baluten urum olong nye i siut.(hukuman bunuh dengan cara membungkus seluruh tubuh pelaku dengan daun pisang yang kering dan kemudian dibakar)

Para pihak yang diberikan sanksi unuh ini boleh memilih salah satu cara pembunuhan ini. Pembunuhan ini dilakukan seluruh masyarakat dan harus ada ikut serta dalam pembunuhan tersebut keluarga dari pihak yang akan dikenai sanksi tersebut, "Keluarga pe urum nunuhe".

$$
\text { Masyarakat Gayo dalam }
$$

menyelesaikan sengketa terlebih dahulu menyelesaikan melalui Peradilan Adat kampung, disebabkan masyarakat memiliki ketertarikan untuk menjalankan hukum edet tersebut. Putusan yang dibuat oleh lembaga adat kampung Sarak Opat memiliki penerimaan penuh dari para pihak yang bersengketa, walaupun diiringi dengan pemberian sanksi berupa denda, namun hal ini begitu mudah diterima masyarakat, karena ada keterkaitan hukum edet dengan pribadi masyarakat Gayo.

Keputusan yang diberikan oleh Sarak Opat mengikat para pihak walaupun tidak tertulis, hal ini disebabkan masyarakat dengan sukarela menjalankan keputusan adat, namun tidak dapat dipungkiri dari sekian banyak yang dapat menerima putusan adat, ada juga pihak yang tidak menerima putusan tersebut, sehingga dalam pelaksanaan putusan para pihak tidak melakukan, namun bagi pihak yang menerima putusan peradilan adat akan menerima putusan dengan senang hati dan melaksanakan putusan peradilan adat tersebut.

Hasil penelitian mengambarkan bahwasanya penerapan sanksi-sanksi adat terhadap para pihak yang melanggar hukum adat, ketertiban dan pelanggaran yang lainnya memberikan efek bagi para pelanggar, sehingga para pihak tidak akan mengulangi kesalahan yang sama, hal ini menunjukan bahwasanya penarapan sanksisanksi adat dalam peradilan adat Gayo sangat berl aku efektif.

Seperti yang dikatakan oleh bapak Jasman $^{7}$, bahwasanya hukum edet dalam masyarakat Gayo begitu melekat dalam setiap pribadi masyarakat Gayo, contohnya ketika ada pihak yang melakukan kesalahan, maka para pihak akan menerima konsekwensi apa saja yang diberikan oleh tokoh adat terhadapnya. Penerimaan ini bukan semata-mata hanya karena putusan adat melainkan karena para pihak memang mengakui kesalahannya, sehingga pemberian sanksi adat terhadapa para pihak

${ }^{7}$ Jasman, Reje Kampung, Toweren Uken, Wawancara, tanggal 07 Juni 2019. 
yang melakukan kesalahan diterima dan dilaksanakan.

Pelaksanaan putusan yang telah ditetapkan oleh aparat kampung, sejauh ini selalu dipatuhi oleh masyarakat, walupun ada beberapa yang terkadang enggan melaksanakannya. Jarang sekali ada bantahan dari masyarakat, karena dalam penyelesaian secara adat kampung, para pihak meminta untuk diselesaikan melalui peradilan adat dengan tujuan untuk berdamai dan bukan untuk menang, dan ketika mereka membawa ke peradilan adat jika sengketanya memerlukan denda maka akan ditetapkan denda, namun jika tidak hanya perlu mendamaikan para pihak saja dan mempersaudarakan mereka. Walaupun sebagian sengketa tidak memerlukan permbayaran denda, namun karena mereka sudah didamaikan, inisiatif dari para pihak/ salah satu pihak sendiri, sehingga ingin kembali mempererat silaturahmi dengan pihak yang bersengketa, maka mereka mengundang pihak yang lainnya dan aparat kampung untuk dijamui makan bersama.

Oleh karena itu menurut bapak Jasman $^{8}$, penyelesaian melalui peradilan adat lebih efektif dan memiliki lebih banyak kelebihan dibandingakn hukum negara, karena hukum negara setelah ada putusan dari pengadilan dalam hal ini pasti hanya dimenangkan salah satu pihak dan salah satunya lagi harus menjalankan vonis yang telah ditentukan, hal ini membuat permasalahan antar pihak yang bersengketa menjadi lebih besar, para pihak tidak akan pernah merasakan damai sebelum yang divonis kalah ini menang juga. Namun berbeda dengan peradilan adat, peradilan adat itu tidak ada yang dimenangkan, dalam arti satu sama lainnya sama, dan dalam peradilan adat itu sangat dipentingkan adanya kerelaan dari para pihak, dan inilah yang membuat masyarakat walaupun bersengketa mereka akan tetap tenang dalam menjalankan aktifitasnya dan para pihak dalam hal ini yang awalnya hubungannya tidak baik dan bersengketa dan setelah diselesaiakn mereka bahkan menjalin hubungan yang sangat erat satu sama lainnya.

Pelaksanaan sanksi adat terhadap pelanggar-pelanggar hukum adat sangat berlaku efektif dalam masyarakat sendiri, karena pemberian sanksi ini membuat para pelaku tidak ingin melakukan kesalahan yang sama, seperti yang dikatakan oleh bapak suhada ${ }^{9}$ pelaksanaan sanksi adat sangat efektif dalam mencegah persengketaan yang muncul dikalangan masyarakat, karena hukum adat itu bertujuan untuk memberikan penyelesaian secara damai walaupun diiringi dengan sanksi, berupa denda dan lain sebagainya, namun denda ini bukan berarti ingin memberatkan para pihak yang bersengketa, melainkan hanya sebagai bentuk pembelajaran, supaya tidak mengulangi lagi.

Sanksi adat yang ada dalam masyarakat gayo merupakan salah satu bentuk pencegahan, seperti yang dikatakan oleh bapak misriadi ${ }^{10}$ dimana pihak yang telah melakukan pelanggaran, akan beratnggungjawab dengan apa yang dilakukan dan berusaha untuk tidak mengulangi kesalahan yang sama, begitu juga dengan masyarakat yang tidak melakukan kesalahan, mereka akan berusaha untuk tidak melakukan keslahan, yang dapat merugikan dan menghancurkan keharmonisan kehidupan bermasyarakat..

\section{SIMPULAN}

Dari penjelesan di atas dapat di ambil kesimpulan

4 Bahwasanya dalam masyarakat Gayo terdiri dari 10 bentuk sanksi, ada sanksi dalam bentuk yang ringan dan

\footnotetext{
${ }^{9}$ Suhada, Reje kampung, Linung Bulen, Wawancara, tanggal 01 Juni 2019.

${ }^{10}$ Misriadi, Reje kampung, Hakim Bale Bujang, Wawancara, tanggal 01 Juni 2019.
} 
berat, penetapan sanksi yang ditetapkan oleh peradilan adat Gayo dilihat dari bentuk pelanggaran yang dilakukan.

$5 \quad$ Penerapan sanksi adat berlaku efektif dalam lingkup kehidupan masyarakat Gayo, sanksi adat memberikan efek jera yang membekas dalam pribadi masyarakat, sehingga disamping sanksi sebagai bentuk hukuman juga sebagai bentuk pencegahan bagi masyarakat supaya tidak mengulangi atau melakukan kesalahan.

\section{DAFTAR PUSTAKA}

Taqwaddin Husin, "Penyelesaian Sengketa/Perselisihan Secara Adat Gampong di Aceh, Kanun Jurnal Ilmu Hukum, 2015, No. 67, Th. XVII,(511-532).

Teuku Djuned dalam Sulaiman, Hukum Peradilan Adat di Indonesia, Pale Media Indonesia, Yogyakarta 2012.

Teuku Muttaqin Mansur, Hukum Adat Perkembangan dan Pembaharuannya di Indonesia, Bandar Publishing, Banda Aceh, 2017.

Teuku Muttaqin Mansur, "Kedudukan Mahkamah Adat setelah Undang-Undang tentang Pemerintahan Aceh”, Kanun Jurnal Ilmu Hukum, 2016, Vol. 18, No. 2, (209-218). 